\title{
ANTIBIOTIC PROFILE OF COMMON PATHOGENS RELATED TO FOOD SAFETY AND HEALTH
}

\author{
X. Voidarou, Technological Educational Institute of Epirus, Arta, Greece, \\ xvoidarou@yahoo.gr
}

\begin{abstract}
A. Alexopoulos, Democritus University of Thrace, Faculty of Agricultural Development, Orestiada, Greece, alexopo@agro.duth.gr
\end{abstract}

S. Plessas, Democritus University of Thrace, Faculty of Agricultural Development, Orestiada, Greece, splessas@agro.duth.gr

E. Bezirtzoglou, Democritus University of Thrace, Faculty of Agricultural Development, Orestiada, Greece, empezirt@agro.duth.gr

\begin{abstract}
Although antibiotics play a crucial role in the health care, their widespread use is increasingly causing some serious health consequences. As a result, the increased duration of hospitalization, the absence from work and the additional cost for social funds are all issues of concern. On that basis, the study of antibiotic profile of microbes isolated from foods is important in order to evaluated the dispersion of resistance, to ensure the foods safety and protect the health of the consumers.

In our study, sixty samples of two traditionally fermented dairy products coming from Cyclades Islands (Greece) were microbiologically examined and the isolated stains of Esherichia coli and Staphylococcus aureus, two common pathogens, were tested against a battery of ten antibacterial agents.

Our results show that $E$. coli strains were sensitive to sulphamethoxazole trimethoprim, streptomycin, cefoxitin, cephalosporin and cirpfloxacin. S. aureus strains were sensitive to sulphamethoxazole/trimethoprim, oxacillin gentamycin, teicoplanin, vancomycin, cephalothin and cirpfloxacin. Both pathogens were moderated resistant to ampicillin, erythromycin, tetracycline and ampicillin.

In conclusion, those traditionally fermented dairy products are in general, free of pathogens resistant to antibiotics and could be considered safe for the consumer's health.
\end{abstract}

Key Words: Soft cheese, microbiological quality, E. coli, S. aureus 


\section{INTRODUCTION}

Antimicrobial resistance is an important public health issue worldwide. The development of resistance in human and animal bacteria has been associated with the extensive use of antibiotics. Particularly, the administration of antimicrobials as growth promoters in animal husbandry (Barber, Miller and McNamara, 2003:700) - progressively banned in EU - has led over decades of use, to selection of resistant bacteria within the microflora of livestock with intrinsic potential transmission to humans through the food chain (Teuber, 2001:439). Horizontal transfer of the genetic determinants from the resistant bacteria to potential pathogens, thus impairing antibiotic treatment of common infections, has been documented through environmental and clinical studies (Franz et al. 2001:4385; Alexopoulos et al., 2006:170). Even, bacterial species which compose the predominant microflora in fermented dairy products may act as reservoirs of antibiotic resistance genes transferable to human opportunistic pathogens like Escherichia coli and Staphylococcus aureus.

In Mediterranean countries, the fermentation of unpasteurized dairy products by their naturally occurring microflora it is a common practice (Devirgiliis et al., 2008:378). Therefore their microbial composition reflects the most representative species addressing the unique and distinct sensorial properties to them. Such dairy products includes various types of mostly soft cheeses like Brick, Limburger e.t.c. Kopanisti (smashed) and Tyrovolia are similar soft cheeses with a peppery, spicy flavor produced mainly in Cyclades Islands (Greece). Kopanisti has received the PDO (Product of Designated Origin) certification from the EU. Both are usually made of cow milk, or a mixture of cow, ewe and goat milk, and congealed and drained in the traditional manner. It takes several months for maturation. During that time more cheese is always added to the mixture for the fermentation to continue, while strains of molds like Brevibacterium linens, Penicillium roqueforti and others, are developed on the surface. Hence, the process involves intensive manual handling of highly perishable ingredients without a final heat step; thereby, offering rich support for bacterial growth.

In this study we aimed to a) to characterize the microbiological quality of both products, b) to isolate and identify possible pathogens and c) to test the susceptibly of those pathogens against a battery of ten antibacterial agents.

\section{MATERIALS AND METHODS}

Sampling was accomplished during the period July - September 2008 and composed of sixty cheese samples, thirty each of the two varieties. Samples, od approximately $500 \mathrm{~g}$ were collected aseptically from the production facilities, placed in plastic bags and transferred to laboratory for analysis. $50 \mathrm{~g}$ from each sample and $450 \mathrm{ml}$ of $\mathrm{G}$ peptone water were homogenized by the aid of a stomacher. $1 \mathrm{ml}$ from the homogenate used for the preparation of the first in a dilution series (up to $10^{-5}$ ) in tubes contained $9 \mathrm{ml}$ Ringer's solution. 
For E. coli, pour plates from serial dilutions of the cheese homogenate $(0.1 \mathrm{ml})$ of VRBA were allowed to solidify and overlaid with 3-4 ml of melted VRBA. The plates were incubated at $44^{\circ} \mathrm{C}$ for $48 \mathrm{~h}$. The pink to red colonies were transferred to tubes containing Brilliant Green Bile (2\%) Broth and to tubes with peptone water. These tubes were incubated in a waterbath at $44^{\circ} \mathrm{C}$ for $48 \mathrm{~h}$. Gas production in the Brilliant Green Bile (2\%) Broth and indole formation in peptone tubes indicate the presence of faecal coliforms (ICMSF 1982; Mackenzie et al. 1948).

For $S$. aureus, serial dilutions of the cheese homogenate were plated on Baird Parker Agar (DIFCO) and incubated at $37^{\circ} \mathrm{C}$ for $48 \mathrm{~h}$. Typical lecithinasepositive colonies were tested for coagulase reaction with Bacto Coagulase Plasma (DIFCO).

Isolated strains were preserved frozen in glycerin brain heart broth until tested for their susceptibility by the Kirby-Bauer disk diffusion method as described by the Clinical and Laboratory Standards Institute (CLSI, 2006).

The employed antibacterial agents and their respective interpretive standards are listed in Table 1.

\section{RESULTS}

From the sixty cheese samples there were eight Escherichia coli and twenty Staphylococcus aureus isolated strains the majority of which recovered from Tyrovolia (8 out of 12 and 11 out of 20 respectively).

Considering the E. coli strains, the $75 \%$ (3 out of 4 ) isolated form Kopanisti were resistant to ampicillin, $50 \%$ in tetracycline, $25 \%$ in chloramphenicol and $25 \%$ in erythromycin. From the eight strains isolated from Tyrovolia, the 25\% were resistant to ampicillin, $50 \%$ to tetracycline, $13 \%$ to chloramphenicol, $50 \%$ to erythromycin and $13 \%$ to gentamycin. All isolated strains were susceptible to sulfamethoxazole/trimethoprin, streptomycin, cefoxitin, cephalothin and cirpfloxacin. Although $50 \%$ of the strains were resistant in two antibiotics, none of them exhibited a multiple resistance profile (Table 2).

Similarly, none of the 20 isolated $S$. aureus strains proven resistant to sulfamethoxazole/trimethoprin, oxacillin, gentamycin, teicoplanin, vancomycin, cephalothin and cirpfloxacin (Table 3). The $44 \%$ of the strains isolated from Kopanisti were resistant to ampicillin and to tetracycline and $33 \%$ to erythromycin. From the $S$. aureus strains isolated from Tyrovolia, $55 \%$ were resistant to ampicillin, $36 \%$ to tetracycline, and $9 \%$ to erythromycin. Only, three strains out of eleven were resistant against two antibiotics and both were isolated from Kopanisticheese. 


\section{DISCUSSION}

In our study we have reported the isolation and antibiotic susceptibly profile of isolates from two soft hand-made cheeses, typical of the Cyclades Islands in Greece, and one of them has been designated as POD. Therefore, due to it's economic importance and considering food safety it is crucial to investigate the potential presence of antibiotic resistant pathogens in this product. Despite some differences in bacterial composition between the two varieties of cheese, it is important to mention the absence of pathogens and the small number of opportunistic pathogens like $E$. coli and $S$. aureus. These bacteria might be of animal origin or as the result of poor handling or storage conditions and don't reflect the actual microflora of the product. This is supported from molecular investigations were the animal or human biovars were identified suggesting that food handlers had been the source of contamination (Jones et al., 2002:82).

It seems that the high titers of live microflora, mostly lactobacilli (data aren't show) and the elevated concentration of salt, protects the product against further colonization of pathogens (Fayol-Messaoudi et al., 2007:657; Mataragas et al., 2008:1835 ; Vassos et al., 2009).

The antibiotics chosen in the present study, are representative of classes of antimicrobial agents (tetracyclines, macrolides, amynoglycosides etc) employed for human and veterinary purposes. Multidrug resistance was defined as resistance to two or more of the antimicrobials tested. This may overestimate multidrug resistance, because several substances of the same antimicrobial class were tested. Nevertheless, each antimicrobial was regarded separately, because bacteria may differ in their resistance status to antimicrobials of the same class. Nevertheless, a minor portion from the isolated strains was observed as acquired a resistance to erythromycin, ampicillin and tetracycline. Half of the E. coli strains and only $15 \%$ of $S$. aureus were resistant to two antibiotics. However, resistance to first and second generation antimicrobial substances, such as fluoroquinolones (ciprofloxacin) and cephalosporines (Cephalothin, Cefoxitin) was absent.

The results of the present study highlighted that, only small numbers of pathogens are present in traditionally fermented dairy products. Moreover, these pathogens are lacking of any noticeable resistance or multi-resistance to common antibiotics and therefore are generally safe for consumers but still poses a potential danger for immunocompromised. Therefore, it is apparent the need for better sanitary education of producers and handlers during food production practices.

\section{REFERENCES}

Alexopoulos, A., Voidarou, C., Stefanis, C., Papadopoulos, I., Vavias, S., Tsiotsias A., Kalkani E., Charvalos E., Bezirtzoglou E. (2006): Antibiotic 
Resistance Profiles and Integrons in Enterobacteriaceae from the Riverside of Evros-Ardas With Respect To Chemical And Waste Pollution. Microbial Ecology in Health and Disease, 18(3):170 - 176.

Barber, D.A., Miller G.Y., and Mcnamara P.E. (2003): Models of Antimicrobial Resistance and Foodborne Illness: Examining Assumptions and Practical Applications, Journal of Food Protection, 66:700-709.

Clinical and Laboratory Standards Institute, (2006): Performance Standards for Antimicrobial Susceptibility Testing. 16th Informational Supplement. Document M100-S16.

Devirgiliis, C., Caravelli, A., Coppola, D., Barile, S., Perozzi, G. (2008): Antibiotic Resistance and Microbial Composition Along the Manufacturing Process of Mozzarella Di Bufala Campana. International Journal of Food Microbiology, 128(2):378-384.

Fayol-Messaoudi, D., Coconnier-Polter, M.H., Moal, V.L., Atassi, F., Berger, C.N., Servin, A.L. (2007): The Lactobacillus Plantarum Strain Aca-Dc287 Isolated From a Greek Cheese Demonstrates Antagonistic Activity in Vitro And In Vivo Against Salmonella Enterica Serovar Typhimurium. Journal of Applied Microbiology, 103(3):657-65.

Franz, C.M., Muscholl-Silberhorn, A.B., Yousif, N.M., Vancanneyt, M., Swings J., And Holzapfel, W.H. (2001): Incidence of Virulence Factors and Antibiotic Resistance Among Enterococci Isolated from Food, Applied and Environmental Microbiology, 67:4385-4389.

Jones, M.E., Kellum, S.S., Porter, M., Bell, And Schaffner, W. (2002): An Outbreak of Community-Acquired Foodborne Illness Caused by Methicillin Resistant Staphylococcus Aureus. Emerging Infectious Disease, 8:82-84.

Mataragas M, Stergiou V, Nychas G.J.J. (2008): Modeling Survival Of Listeria Monocytogenes in The Traditional Greek Soft Cheese Katiki. Journal of Food Protection, 71(9):1835-1845.

Teuber, M. (2001): Veterinary Use and Antibiotic Resistance. Current Opinions In Microbiology, 4:439-499.

Vassos, D., Bezirtzoglou, E., Voidarou, C., Alexopoulos, A., And Maipa, V. (2009): Survey of Probiotic Enterococci from Traditional Dairy Products and Their Impact Upon the Infant Intestinal Microbiota. Journal of General and Applied Microbiology (In Press). 
Table 1: Interpretive standards (breakpoints in $\mathrm{mm}$ ) for the antibiotics used in the study.

\begin{tabular}{|l|r|r|r|r|r|}
\hline \multicolumn{1}{|c|}{ Antibiotic } & \multicolumn{1}{c|}{ Code } & \multicolumn{1}{c|}{$\mu \mathrm{g} / \mathrm{disk}$} & Resistant $^{\mathrm{a}}$ & Intermediate $^{\mathrm{a}}$ & Sensitive $^{\mathrm{a}}$ \\
\hline Ampicillin & AMP - 10 & $10 \mu \mathrm{g}$ & $\leq 13$ & $14-16$ & $\geq 17$ \\
\hline $\begin{array}{l}\text { Trimethoprim - } \\
\text { sulfametoxazole }\end{array}$ & SUT -25 & $\begin{array}{r}1.25 / 23.75 \\
\mu \mathrm{g}\end{array}$ & $\leq 10$ & $11-15$ & $\geq 16$ \\
\hline Streptomycin & STR -10 & $10 \mu \mathrm{g}$ & $\leq 11$ & $12-14$ & $\geq 15$ \\
\hline Gentamicin & GEN -10 & $10 \mu \mathrm{g}$ & $\leq 12$ & $13-14$ & $\geq 15$ \\
\hline Tetracycline & TER- 30 & $30 \mu \mathrm{g}$ & $\leq 14$ & $15-18$ & $\geq 19$ \\
\hline Cefoxitin & CEF- 30 & $30 \mu \mathrm{g}$ & $\leq 14$ & $15-17$ & $\geq 18$ \\
\hline Cephalothin & CEP -30 & $30 \mu \mathrm{g}$ & $\leq 13$ & $15-17$ & $\geq 18$ \\
\hline Ciprofloxacin & CIR-5 & $5 \mu \mathrm{g}$ & $\leq 15$ & $16-20$ & $\geq 21$ \\
\hline Nalidixic acid & NAL-30 & $30 \mu \mathrm{g}$ & $\leq 13$ & $14-18$ & $\geq 19$ \\
\hline Chloramphenicol & CHL-30 & $30 \mu \mathrm{g}$ & $\leq 12$ & $13-17$ & $\geq 18$ \\
\hline
\end{tabular}

${ }^{a}$ Breakpoints according to CLSI, 2006

Table 2: Results of antibiotic susceptibility for the $E$. coli isolated strains.

Percentages indicate the resistant strains.

\begin{tabular}{|c|c|c|c|c|c|c|c|c|c|c|c|}
\hline \multirow[t]{2}{*}{ Sample } & \multirow{2}{*}{$\begin{array}{l}\text { Isolated } \\
\text { strains }\end{array}$} & AMP & SUT & STR & GEN & ERI & CEF & $\overline{\mathrm{CHL}}$ & CEP & CIR & TER \\
\hline & & $\begin{array}{l}\mathrm{N} \\
\%\end{array}$ & $\begin{array}{l}\mathrm{n} \\
\%\end{array}$ & $\begin{array}{l}n \\
\%\end{array}$ & $\begin{array}{l}n \\
\%\end{array}$ & $\begin{array}{l}\mathrm{n} \\
\%\end{array}$ & n \% & $\begin{array}{l}n \\
\%\end{array}$ & n \% & $\begin{array}{l}n \\
\%\end{array}$ & $\begin{array}{l}\mathrm{n} \\
\%\end{array}$ \\
\hline $\begin{array}{l}\text { E. coli } \\
\text { from } \\
\text { Kopanisti }\end{array}$ & 4 & $\begin{array}{l}3 \\
75\end{array}$ & - & - & - & $\begin{array}{l}1 \\
25\end{array}$ & - & $\begin{array}{l}1 \\
25\end{array}$ & & - & $\begin{array}{l}2 \\
50\end{array}$ \\
\hline $\begin{array}{l}\text { E. coli } \\
\text { from } \\
\text { Tyrovolia }\end{array}$ & 8 & $\begin{array}{l}2 \\
25\end{array}$ & - & - & $\begin{array}{l}1 \\
13\end{array}$ & $\begin{array}{l}4 \\
50\end{array}$ & - & $\begin{array}{l}1 \\
13\end{array}$ & - & - & $\begin{array}{l}4 \\
50\end{array}$ \\
\hline Total & 12 & $\begin{array}{l}5 \\
42\end{array}$ & - & - & $\begin{array}{l}1 \\
8\end{array}$ & $\begin{array}{l}5 \\
42\end{array}$ & - & $\begin{array}{l}2 \\
17\end{array}$ & - & - & $\begin{array}{l}6 \\
50\end{array}$ \\
\hline
\end{tabular}

Antibiotic abbreviations: AMP, Ampicillin; SUT, Sulfamethoxazole/trimethoprin; STR, Streptomycin; GEN, Gentamicin; ERI, Erythromycin; CEF, Cefoxitin; CHL, Chloramphenicol; CEP, Cephalothin; CIR, Ciproflocacin; TER, Tetracycline. 
Table 3: Results of antibiotic susceptibility for the $S$. aureus isolated strains.

Percentages indicate the resistant strains.

\begin{tabular}{|c|c|c|c|c|c|c|c|c|c|c|c|}
\hline \multirow[t]{2}{*}{ Sample } & \multirow[t]{2}{*}{$\begin{array}{l}\text { Isolated } \\
\text { strains }\end{array}$} & AMP & SUT & OXA & GEN & ERI & TEI & VAN & CEP & CIR & TER \\
\hline & & $\begin{array}{l}\mathrm{N} \\
\%\end{array}$ & $\begin{array}{l}\mathrm{n} \\
\%\end{array}$ & $\begin{array}{l}n \\
\%\end{array}$ & $\begin{array}{l}\mathrm{n} \\
\%\end{array}$ & $\begin{array}{l}\mathbf{N} \\
\%\end{array}$ & $\begin{array}{l}\mathrm{n} \\
\%\end{array}$ & $\begin{array}{l}\mathrm{n} \\
\%\end{array}$ & n \% & $\begin{array}{l}\mathrm{n} \\
\%\end{array}$ & $\begin{array}{l}n \\
\%\end{array}$ \\
\hline $\begin{array}{l}S . \\
\text { aureus } \\
\text { from } \\
\text { Kopanisti }\end{array}$ & 9 & $\begin{array}{l}4 \\
44\end{array}$ & - & - & - & $\begin{array}{l}3 \\
33\end{array}$ & - & - & - & - & $\begin{array}{l}4 \\
44\end{array}$ \\
\hline $\begin{array}{l}S . \\
\text { aureus } \\
\text { from } \\
\text { Tyrovolia }\end{array}$ & 11 & $\begin{array}{l}6 \\
55\end{array}$ & - & - & - & $\begin{array}{l}1 \\
9\end{array}$ & $\begin{array}{l}- \\
-\end{array}$ & - & - & - & $\begin{array}{l}4 \\
36\end{array}$ \\
\hline Total & 20 & $\begin{array}{l}10 \\
50\end{array}$ & - & - & - & $\begin{array}{l}4 \\
20\end{array}$ & - & & - & $\begin{array}{l}- \\
-\end{array}$ & $\begin{array}{l}8 \\
40\end{array}$ \\
\hline
\end{tabular}

Antibiotic abbreviations: AMP, Ampicillin; SUT, Sulfamethoxazole/trimethoprin; OXA, Oxacillin, GEN, Gentamycin, ERI, Erythromycin; TEI, Teicoplanin, VAN, Vancomycin, CEP, Cephalothin; CIR, Ciproflocacin; TER, Tetracycline. 